\title{
SIR WILLIAM OSLER AND FRENCH MEDICINE
}

by

\section{CHARLES COURY*}

'ONLY those of us, Mr. President, who have had the good fortune to hold the distinguished position which, by your kind grace, Sir, I hold today, only those who have delivered the Oslerian oration, can appreciate the extraordinary difficulties besetting a subject, every aspect of which has been considered, very often too, by men who have brought to the task a combination of learning and literary skill at once the envy and the despair of their successors.'

I believe that this is the fairest homage that can be paid to William Osler: to repeat and to apply to him the very words he spoke, exactly sixty years ago, about William Harvey.

When your President, Dr. Noël Poynter, and your Secretary, Dr. Geraint James, invited me to speak before your honourable company, they did me a great favour, for which I thank them most heartily. But, by giving me their suggestion for the subject of this Commemorative Address, they brought me to grips with a thankless and difficult task. To confine, for the sake of the argument, the influence of such a universal man as Osler to the proportions of one single country, is to cut down most regrettably the size of the man and to set very artificial limits to the scope of his work. Did not he himself write: 'The true student is a citizen of the world ... The great minds, the great works transcend all limitations of time, of language, and of race'. The sources of his culture, the influence of his scientific work, the lessons of his teaching, the greatness of his humanism, the far-reaching influence of his thought, and the quality of his literary talent are a common treasury that defies fragmentation. Like the flight of the eagle, the genius of learned men knows no frontiers . . Since however, such are the requirements of the moment, I shall strictly confine myself to the flattering mission that $I$ have been given.

The theme I am about to develop makes up a harmonious triptych. On the left-hand panel, Osler himself inscribes the debt that his medical knowledge and his enlightened humanism owe to France, a country for which he has always shown a great deal of affection and admiration. The middle panel carries the testimony of the friendly personal relations and of the understanding intellectual exchanges which the professor of McGill University, the University of Pennsylvania, Johns Hopkins Hospital and Oxford University, established during the course of his stays in France. Finally on the right-hand panel, balancing the first, I shall make a reckoning of the debt which contemporary French Medicine owes to William Osler in many fields.

Like many other physicians outside France during the mid and late nineteenth century, particularly in the English-speaking and German countries, Osler harks back

* Oslerian Oration, delivered at the Osler Club Annual Dinner, 12 July 1966. The author is highly indebted to Mr. B. C. Boeglin for his kind help in the translation. 


\section{Coury}

to the French School of Clinical Anatomy, whose golden age flourished with Laennec and his many successors, exerting a deep influence on medical research until the turn of the century. With Osler, this French influence blended most profitably with the training he had received in Canada, in England, in Berlin and in Vienna. Actually, Osler's interest in French scientists and writers leads us much farther back into the past. His appreciation of French literary culture is reflected in this sentence: 'It is not often that a Frenchman makes a mistake in matters literary.' He pays a passing tribute to Rabelais. He cultivates Montaigne, whom he calls in turn an 'old rascal' and a 'dear old man so full of good sense'; he easily forgives him for the frequently extreme judgments he passed on our profession: 'He is rather hard upon the Doctors, but I daresay he had good reason in those days.' He bows before the logic of a Descartes and the critical mind of a Voltaire. From the original texts and a few works, such as Bayle's Biographie Médicale or Dechambre's Dictionnaire, he absorbs in retrospect the atmosphere which prevailed in French universities at the time of the Renaissance, in the days of Symphorien Champier, Guinter d'Andernach, Jacques Sylvius, and Vesalius. He is particularly interested in the French positions before and after Harvey's discovery. He is captivated by the personality of Michel Servet, the Spaniard who became a Frenchman by adoption; he retraces his dramatic story with as much erudition as human warmth; he particularly dwells on his stay in Vienne, a small town near Lyon, and the birthplace of one of Lady Revere Osler's direct ancestors, who was exiled as a consequence of the Revocation of the Edict of Nantes. As a conscientious historian, Osler consults the few remaining prime sources, and he pores over one of the only two copies extant of the Christianismi Restitutio at the Bibliothèque Nationale in Paris. In 1905, he even becomes one of the active members of the Committee for the erection of a monument to the memory of this man who was the victim, in effigy, of the blind fanaticism of the Catholic Inquisition, and who was burned in the flesh at the stake of Calvinist sectarianism; Servet was condemned, not for having discovered incidentally the lesser circulation, but for wanting to reform the untouchable Dogma of the Holy Trinity, 'dreaming to restore primitive Christianity'.

Moving from Harvey's precursors to his contemporaries, Osler shows his interest in Jean Riolan the Younger, an unrepentant reactionary and an indomitable adversary of the theory of the blood circulation, as well as of the use of quinquina and laudanum, so dear to Sydenham. The Oxford Regius shows a passionate indulgence for Gui Patin, whose lively style and wit he admires unconditionally, as the expression of his epistolary verve serving intelligent traditionalism. He even forgives him for his obstinately retrograde opposition to the 'sweet dream' (sic) of Harvey and other 'circulationists', whom he would never acknowledge as anything but charlatans: -... To such a lover of books and of good literature everything can be forgiven ... With all his faults, particularly his scandalous lack of charity, one cannot but feel the keenest sympathy with this dear old man.' In a relevant study of the various editions of his Letters (1630-1672), Osler criticizes that published by Pierre Pie in 1911, and he displays unusual vehemence in both words and judgment, so great is his concern for keeping Patin's work intact. No doubt, Osler pays a debt of gratitude to the redoubtable Dean of the 'Most Salutary' Faculty of Paris, by giving him credit for 


\section{Osler and French Medicine}

his appreciation of Sir Thomas Browne's Religio Medici and for the care he took of his son, a student in Paris; we all know what a penetrating study Osler devoted to this great English philosopher and moralist, whose work, albeit tinged with humour, and scepticism, yet retains its full measure of seriousness.

Osler is fully aware of modern medicine's debt to the French pioneers of the beginning of his century, and he never misses an opportunity of recalling this fact. He respectfully bows before the figure of Pinel and Cabanis. He pays a vibrant homage to Corvisart, ' . . . who had already revolutionized the teaching of medicine. Today, Paris still follows the great master's method-the morning ward visit, and afterwards the amphitheatre lecture ... Here, too, was working the man who was to influence Laennec strongly, Bayle; and for a short time he had the inestimable advantage of the instruction and example of Bichat.' Bichat, on whose tomb Osler made a point of placing a wreath on All Saints Day, 1908, at the Père-Lachaise Cemetery, and of whom he wrote: ' . . . that rare genius who started a revolution in medicine before he was thirty, and who died at thirty-two, leaving a name which is reverenced throughout the world.' Osler writes in another paper: ' . . . The story of Laennec, discoverer of auscultation, and founder of modern clinical medicine, has been told and retold, but not all told.' Having devoted himself to physiology at the beginning of his career, it was quite natural that Osler should display unconditional admiration for its founder.

Strongly inspired by the biography published by Alfred Rouxeau under the title Laennec before 1806, Osler painted a vivid picture of the brilliant Breton's difficult childhood and of his years of study in Nantes. ' . . . At last, the fledgeling took flight, and in 1801, with a light heart and a light pocket, with only eight hundred francs, the young Théophile set out to conquer Paris.' This cult for the French physiological School was instilled in him by his master, Dr. Howard. Thus, he writes in The Student Life: 'When I first, a senior student, came into intimate contact with him, in summer 1871, the problem of tuberculosis was under discussion, stirred up by the epochmaking work of Villemin and the radical views of Niemeyer.' And further: 'Every lung lesion at the Montreal General Hospital had to be shown to him, and I got my first-hand introduction to Laennec, to Graves and to Stokes . . . So, when the International Congress of Tuberculosis was held in Paris from 2 to 7 October 1905, under the honorary chairmanship of Emile Loubet, Casimir Périer, and Léon Bourgeois, William Osler did not fail to attend, together with Perkins, Bulstrode, Williams, and Matheson of the British delegation led by Sir William H. Broadbent. It was for him an opportunity to meet Hérard, Chauveau, Brouardel, Lannelongue, Letulle, who was still an Agrégé at the time, and who was to become professor of the history of medicine seven years later, Bouchard, and finally Landouzy, whom he was to meet again in Paris in 1908. But let us see what Cushing had to say about this in his Life of William Osler: ' . . The congress was a great success. Paris always stages these things well. The congressists were welcomed at the Hôtel-de-Ville, that incomparable municipal building; the meetings were held in the Grand-Palais; there was a banquet and a reception at the Elysée by Emile Loubet; also a gala performance at the Châtelet Theatre, where, among other items, Le Médecin malgré lui was presented; and much else.' Contemporary reports indeed spoke highly of the splendid arrangements for 


\title{
C. Coury
}

this Congress. The official events, the receptions given by the great newspapers of the day-the Figaro, the Matin-were most brilliant; Hérard's was held at the Hôtel Continental; the Office of the President of the Republic invited no less than 3,500 guests to the soirée on Saturday, 7 October. The congressists heard many speeches; Calmette, Préfet Lépine, and President Loubet spoke in person; the closing address was given by Emil von Behring.

Osler acquired from his master, Palmer Howard, a special veneration for the memory of Louis. He saw in him not only one of the first specialists of tuberculosis, nor the man whose great moral worth and whose scruples as a scientist prompted him to give up a comfortable position in the Crimea to devote himself to the study of diphtheria and typhoid fever in the light of the clinic, autopsy and the statistical method. As he wrote in 1897 in the Bulletin of the Johns Hopkins Hospital, Osler mainly acknowledged in Louis one of the French physicians who had the greatest influence on young American medical men. The Congress of 1905 gave Osler and a few of his friends the opportunity of expressing this homage in a touching manner. In this connection, let us read again the irreplaceable biography that Cushing left us:

\begin{abstract}
Some twenty of the American members had gathered together on Thursday 5 October for a luncheon, and, acting on an inspiration, Osler suggested that they make a pilgrimage to Louis's grave and place a wreath upon it. But as no one, not even the French physicians who were consulted, had any idea where Louis was buried, it was some time before the site of the forgotten tomb of the famille Louis, in which Louis, his wife and son rest, in the cemetery of Montparnasse, was disclosed. There the band of sixteen Americans repaired, by one of whom, subsequently, the story was most feelingly told (meaning A. C. Klebs). Crowded in the narrow room of the doorkeeper's house, they waited for an autumnal downpour to cease, while a few rainsoaked gendarmes peeped through the window, wondering what these foreign-looking gentlemen could intend. The shower ceased, and as the band of intimate friends, bound together by a great common interest, stopped at the door of the mausoleum which held Louis's remains, Osler placed a wreath of autumn leaves on the steps and told in a few words the simple story of Louis's life, which has no parallel in the profession; of the sad death of his son at the age of eighteen from tuberculosis; of his own death from the same disease at the age of eighty-five; of his special claims to remembrance, not so much his attempt to introduce mathematical accuracy into the study of disease, as his higher claim to have created the American school of clinical medicine through his pupils. After paying this tribute of deep solemnity and meaning to the great French master, back they went silently to their work at the congress.
\end{abstract}

We can all agree with Cushing's opinion: no possible act could have touched French sentiment more deeply.

Three years later, finding himself in Paris on a beautiful, sunny day on the eve of All Saints Day, Osler again performed this pious gesture. Rather, let him speak:

I had a little pilgrimage of my own to make on Saturday afternoon to the cemetery of Montparnasse ... Then I turned and sought the tomb of a man whom my teachers taught me to honour ... In Odessa a young Frenchman met with an experience which has happened to every thoughtful physician. An epidemic of diphtheria with its awful mortality struck the terror of helplessness and hopelessness into his heart, and he decided to return to Paris, again to take up the student life and to endeavour to know more of the disease before he undertook its treatment. An old friend at the Charite Hospital gave him the opportunity he sought, and for years he worked quietly at the problems of the disease. With the publication of his book on typhoid fever and on tuberculosis, Louis found himself famous, and he ranks today with the great French physicians who laid the foundation of modern clinical medicine . . . My old teacher, Palmer Howard, a man of the same type, taught me to reverence his memory, but my pilgrimage had another inspiration-gratitude to the devoted teacher and friend of the veterans whom I loved in the profession in the United States-W. W. Gerhard, Oliver Wendell Holmes, Henry I. 


\section{Osler and French Medicine}

Bowditch, George C. Shattuck and Alfred Stille. But as I laid my wreath in front of the grille of the tomb, it was not of these men I thought, but of young James Jackson whom Louis loved as a son and who was stricken at the very onset of a brilliant career . . . (And to Louis himself came a similar tragedy. Inside the tomb is a slab of marble to the memory of his only son, a medical student who died of tuberculosis in his eighteenth year. At dinner one evening, Dr. Bucquoy, President of the Academy of Medicine, who was Louis's last intern, told me the story of the illness-a sudden hemoptysis and then a long, lingering progress to the grave.)

Osler writes: 'There are more statues to medical men in Paris than in Great Britain and the United States put together; many of the hospitals are called after the men who have shed glory on France-Bichat, Laennec, Broussais and Claude Bernardand in the hospitals themselves each ward is dedicated to the memory of some distinguished man. Every Frenchman is a hero-worshipper, and has a master, dead or alive, whom he adores. Among the men of this generation you can tell very quickly who have been under Claude Bernard or Trousseau or Charcot or Potain.' To echo what he calls 'the extraordinary reverence of the French', when praising French medical and biological science, Osler does not merely consider the glories of the past; he pays his contemporaries the homage that he believes he owes to them. Binding in one same sheaf of men of genius, a Frenchman, a German, and an Englishman, he exclaims with feeling: 'Pasteur, Koch and Lister are Varro, Fracastorius and Spallanzani in the nineteenth century garb.' Sir William who was one of the greatest technicians of modern medical teaching, proclaimed his ardent faith in cultural exchanges and internationalisation of knowledge: 'I care not in what subject he (the student) may work, the full knowledge cannot be reached without drawing on supplies from lands other than his own ... If the work is to be effective, he must keep in touch with scholars in other countries.'

During the winter of 1908-1909, having already reached the pinnacle of his glory, the great master of Oxford himself gave the example: he had no trouble finding once more the student spirit to ramble through old Europe,-France and Italy-where he expected to be intellectually rejuvenated: 'I am off on a brain dusting. I have not had a winter free for thirty-four years, and have long wished to see more of Paris and French medicine, so I am here for three months.' He stayed in Paris in a comfortable apartment, placed at his disposal by an American friend, Marguerite Chapin, 44 avenue d'Iéna, from 1 October until 15 January. It was certainly not a holiday. His correspondence and several articles written by him, more particularly in the Journal of the American Medical Association, enable us to put together the details of his extraordinary touristic, cultural, medical and social activity during his stay with Lady Grace Osler and their beloved son, who joined them for his Christmas holidays. Sir William took advantage of an exceptionally sunny autumn to explore the capital thoroughly, with a student of the Ecole des Chartes, who served as his guide and his French tutor. While waiting for the university to open again in early November, he assiduously frequented the libraries: the Nationale, the Mazarine, those of the Sorbonne and of the Faculty of Medicine, relentlessly looking out for a rare edition or an interesting manuscript, such as a Gui Patin, a Pourfour du Petit, a Bichat, a Laennec, or a Broussais. 'They have given me a special room at the Ecole de Médecine Library and I am browsing in some interesting 16th century books.' Our faculty has in its keeping two touching tokens of his gratitude. In 1909, soon after his return 


\section{Coury}

to England, Osler arranged for one of the thirty copies of Vesalius' Tabulae anatomicae sex, reprinted in 1874 for Sir William Stirling Maxwell, to be sent to the Library of the Faculty. Above all, in December 1917, a few months after his son's heroic death, Osler decided to bequeath to the Paris Faculty a valuable copy of Ambroise Paré's Anatomie universelle du corps humain. Osler had bought it by telegram in February 1916, from the Paris book dealer, Lucien Gougy, for the respectable sum of 250 francs of the day. In the Annals of Medical History of 1917, Osler, himself an enthusiastic bibliophile, retraced the history of this very rare edition which was printed in Paris by Jehan Le Royer in 1561, only two copies of which were known to Malgaigne in 1840. Osler's gracious and generous character prompted him to write: ' . . . The fitness of things demands that this copy should return ultimately to France, to the great collection of the École de Médecine.' He was more specific on a blank page of the book: 'If, at the time of my death, no copy is in the Library of the Faculté de Médecine, Paris, I desire my executors to send this with my compliments.' Professor Henri Roger (1860-1946), who was the dean at the time, had officially accepted the gift beforehand in a letter dated 16 January 1918. This book bears Osler's handwritten annotations, an eloquent witness of Osler's feelings for France, and it has been, since 1924, one of the fairest possessions of our Library.

In a letter to one of his friends, Osler gave an idea of the way he spent his time in Paris in 1908: 'I have had a regular routine. 8.30 off to the Hospital where they make the visit at 9 sharp. Lunch at 12.30 and then at 2.30 we go somewhere or I slip to one of the Libraries.' And elsewhere: 'I am up to my eyes in work- too much to see.' He went to a reception at the Académie Française, listened to Bergson and attended lectures at the Sorbonne. He took the time to finish revising his Principles and Practice of Medicine which had been published in French, a year before, as a translation by Salomon, Landouzy's chef de clinique, with a short preface by Pierre Marie. Among countless other occupations and upon the recommendation of a mutual friend, Dr. Hugh Young, urologist at the Johns Hopkins Hospital, he took the opportunity while in Paris to entrust the American Seymour Thomas-one of the outstanding portrait painters of his day-with the task of painting his portrait; the sitting took place in the artist's studio at 11 bis Impasse Ronsin, late morning or about noon, when Osler returned from the nearby Hôpital Necker.

Deliberately avoiding the American colony in Paris, Osler strove to become intimately familiar with French medicine. The contacts he made at all levels of the hospital and university hierarchy were numerous, cordial, clearsighted and instructive. He established or reinforced relations with his most eminent Parisian colleagues. He spoke of them on several occasions with sincere admiration and warm sympathy: let us quote a card to Jacobs, written on 20 November: 'In full swing, such busy days-hospital every morning-Raymond, Marie, Dieulafoy, Vaquez, have been most kind. Moutier, Marie's second intern, has given me a splendid demonstration of the aphasia work. I go to the Académie with Chauffard every week, and to the Société des Hôpitaux with Rist who is a most delightful fellow.' Edouard Rist (18711956), who spoke fluent English, had been appointed "Médecin des Hôpitaux" three years earlier. Osler and Rist subsequently came to a close friendship. In his unpublished diary, the latter refers to Osler as his master and excellent friend. Rist 


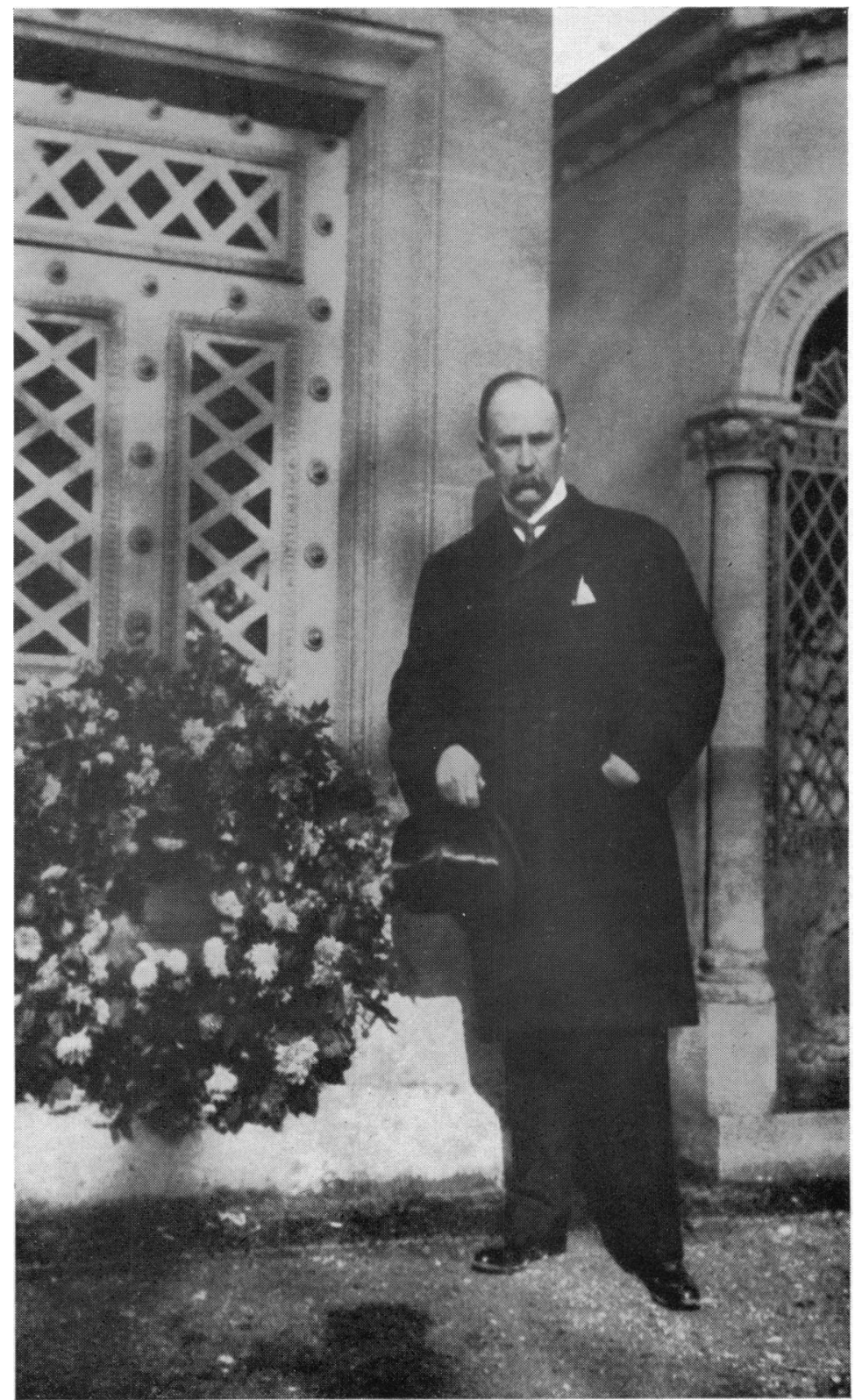

Figure 1. Sir William Osler (1849-1919). From a photograph taken at the Père-Lachaise Cemetery, Paris, in 1905 (see pp. 4-5). (Reproduced by kind permission of the Osler Club of London.) 


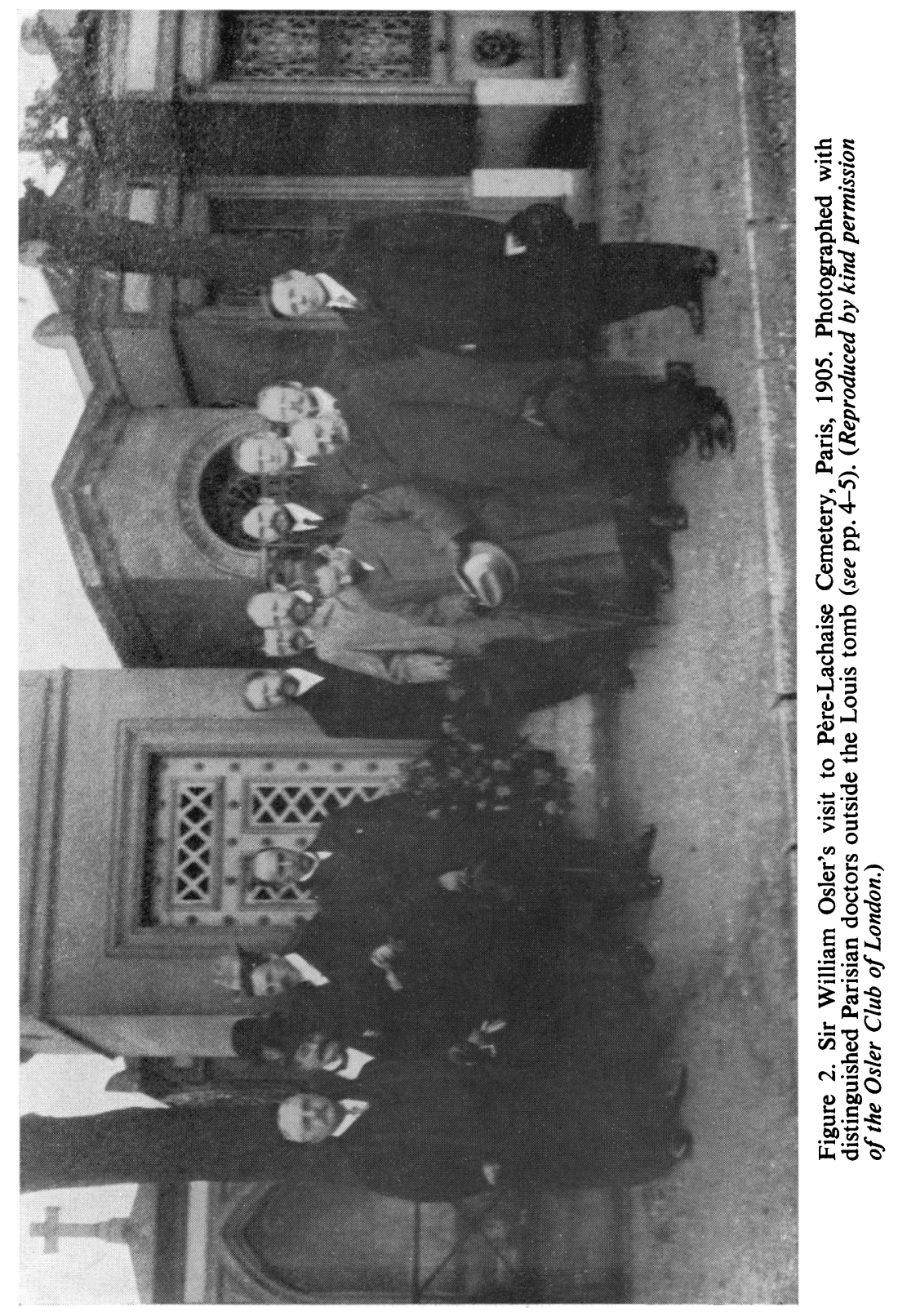




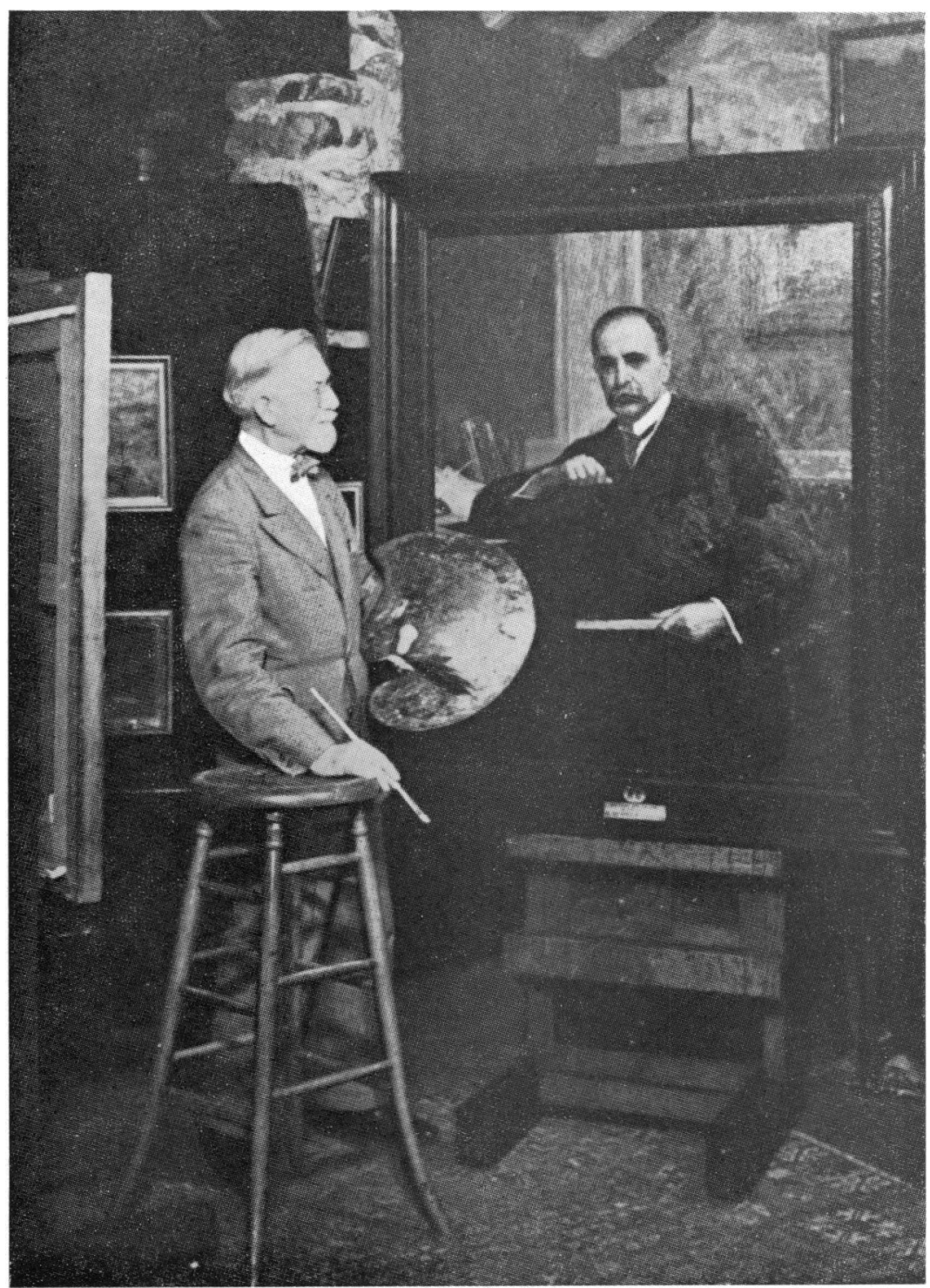

Figure 3. Mr. Seymour Thomas and the portrait of Sir William Osler. (From Bull. Hist. Med., 1949, 23, facing p. 353. Reproduced by kind permission of the Editor). 


\section{Osler and French Medicine}

and his wife had Sir William and Lady Osler as guests at their home in Paris. Around 1912, Osler invited Rist to deliver a lecture and attend a reception at Christ Church, Oxford; he favoured the admission of his French friend to the Royal College of Physicians. In return, Rist presented him with a copy of Morel's book on Histology illustrated by Villemin's own hand (oral information kindly provided by Madame Rist).

About Pierre Marie, the great neurologist to whom we are indebted for the description of acromegaly and pulmonary hypertrophic osteoarthropathy, Osler writes in a letter: 'Marie is Professor of Pathology now and lectures on general pathology three times a week. He is a delightful fellow.' All those who came close to this great clinician would have readily subscribed to this sympathetic judgment. Twenty years later, Marie wrote in the Memorial Volume, speaking of Osler as an educator: 'Sir William Osler was not only a great physician, but also a superior being.' Osler met Bucquoy, President of the Medical Academy, Bouchard the irascible President of the Jury d'Agrégation, Crouzon the eminent neurologist and of course the great Widal; he dined at Chauffard's and at Raymond's. Landouzy, the Dean of the Faculty, invited him to a sumptuous dinner, followed by a reception given for the Professors and the Agrégés. 'I have seen a great deal of my colleagues and we have had several ordeals of enormous dinners (enormous in every sense of the word!) but it has been great fun.' 'It is really delightful meeting these men and staying here long enough to get to know them ... Such nice men; but Dieulafoy embarrasses me by making me sit at his right hand in his clinic (Hôtel-Dieu), and Raymond (Salpêtrière) insists that I have an armchair on his platform.' Like the hospitals, the learned societies took pride in his presence. Laveran introduced him to the Tropical Pathology Society which met at the Institut Pasteur. On 11 December, at the Société Médicale des Hôpitaux de Paris presided over by Letulle and by Chauffard, he read a paper on chronic infectious endocarditis; at the same meeting, Professor William Osler (of Oxford) was elected by acclamation a corresponding member of the Society. The National Academy of Medicine did him the same honour on 2 June 1914, on the strength of a report written by Jalaguier on 26 May, under no. 2627; it says among other things: 'Among his main publications, we shall mention his Text Book which has been translated into French. He is the Director of the great Treatise of Medicine by English speaking authors. He has also published many memoirs on infantile cerebral palsy, chorea, angina pectoris and stomach cancer. We are also indebted to him for several interesting studies on various questions relating to the history of medicine. Let us add that Mr. Osler is quite rightly considered to be one of the most remarkable writers in English medical literature.' The starkness of the style of this report no doubt follows good academic tradition; but it fails to do justice to the scientific work of one of the great masters of medicine and only gives a pale reflection of his human warmth on the eve of a war in the course of which his only son Revere was to fall defending French soil. The announcement of Osler's death to the Academy by its President, Laveran, at the meeting of 2 March 1920, was less laconic; we shall quote only the ending: 'He was one of the first to recognize in malaria patients in America the same hematozoon which I discovered myself in the malaria patients of Algeria, this being an important confirmation of the pathogenic role of this parasite. William Osler was an eminent clinician, a remarkable professor, a writer who is 


\section{Coury}

justly renowned for his clarity and his precision; he was furthermore a likeable man, who was most affable and who counted very many friends. His death is a great loss for medical science and in particular for Oxford University. In the name of the Medical Academy, I extend my most sincere condolences to the family of our illustrious colleague whom we greatly miss.' (Unanimous approval).

But to return to the last few months of the year 1908, when Osler made such progress in becoming familiar with French medicine, he was not satisfied with frequenting the great masters and judging their methods by their most brilliant successes. He insisted on steeping himself in the everyday life of the hospitals and the university; with his characteristic curiosity and conscientiousness, he carefully studied every department at every level of French medicine, and this enabled him to make certain assessments of our system which are strangely exact and extraordinarily fair; among foreigners, Osler is one of those who have best known the French medical organization of his day, which, by the way, has survived until these very last years. He makes a very favourable assessment of the Parisian student: 'As I have seen him during the past three months at work in the hospitals, the Paris medical student is a very hard-working fellow, keenly alive to the importance of scientific and practical medicine, and with a charming touch of human sympathy with the patient entrusted to his care'; and further: 'As elsewhere the Paris medical students are in three groups-good, indifferent and bad. A casual visitor to the laboratory and the hospitals gets only a general impression, and that given to me was of a very industrious hard-working set of men. From the start the student knows that success depends on his brains, or on a facility to use them in a certain way. One word is stamped on his consciousness-"concours", the public examination for positions of all sorts so characteristic, as I have said, of the French system. He is early made to realize that every single step in his career until he reaches an "agrégé" professorship depends on how he conducts himself at the "concours". This must have a very steadying effect on a young fellow ....

'One advantage the French medical student has over all others ... In Paris, the hospital is his home ... Attendance during the first year is not compulsory, but the practice is universal. The hospital is everything; the medical school is-well, quite a secondary consideration'. This surprised discovery is followed by a critical discussion: 'Much as I love hospital work and much as I believe in the life of the student in the hospital, I do not think that, with our present congested curriculum, it is an advantage to begin clinical work at once. It may be good for the medical student morally, but I am sure it is bad for him intellectually . . . One difficulty, almost insuperable, in ward teaching, is the crowding and congestion which make it profitable only for the inner ring. Twenty should be the limit. I counted fifty-five one morning in a ward at the Hôtel-Dieu ... On the whole I have the impression that the Paris medical student gets very close to the patient, and, if diligent and successful in becoming successively externe and interne, he certainly has opportunities of an altogether exceptional character. I am not so sure about the ordinary "stagiaire", who seems rather out in the cold. Many reforms are under discussion.' Sixty years have gone by: the arguments are not yet over and the reforms are not yet noticeably final.

Osler makes an excellent analysis of those two functions of a hospital which are specifically French: l'externat (externship) and l'internat (internship) which are often 


\section{Osler and French Medicine}

misunderstood abroad. "A student is allowed to compete in the externe "concours" in his second year; the examination is not severe; . . . a good deal of the important work of the hospital is done by them.' The internship, l'Internat des Hôpitaux, seems to him to be a remarkable institution: 'The interne is a special French product, unlike anything else in the medical world. He is still a student, yet he has all the responsibility of a practitioner and he is house surgeon, house physician, clinical assistant, laboratory assistant, special research student rolled into one. He lives in the hospitals for four years, a sufficient length of time to give him an exceptionally good education and a large experience. He comes into delightful relations with his chiefs, he lives in charming comradeship with his fellows, and if there is anything in him he finishes his term with an admirable bit of original work which appears as his thesis for the M.D. . . . A first-class interne is about the best hospital product with which I am acquainted, and it is no wonder that as a body the "internat" is looked on as the special glory of French medicine . . . It is no wonder that we look on the Paris theses (and those also of the other French schools) as containing some of the most valuable literature of the profession. . . The great prize of the student's life, the "internat", is the pride of the student body, and, indeed, past and present, it is the pride of the profession of the country, since it embraces its select and elect.' It could not have been better expressed, with fewer words or greater praise. 'When his term is finished an ambitious interne will try the "concours" for the position of head of one of the faculty clinics (or, if his tastes lie in the direction of the laboratories, for one of the many positions vacant every year in connection with them). If he decides to stay in Paris in a few years he will get ready for the great hospital "concours"for the position of physician, surgeon or specialist-and then he will contest for an "agrégé" professorship, which is as far as his individual efforts can carry him. The final lot, the professorship, is in the lap of the gods, and in the disposing of it, as is well known in Paris and elsewhere, brains are only one factor.' The chairs of clinical medicine then numbered four, and they were occupied by Dieulafoy, Landouzy, Debove and Hayem; at the moment there are seven, in addition to the specialized clinics.

Osler remained strongly impressed by the quality of teaching in Paris hospitals. He gave several examples which he noted during his stay: 'The clinical lecture is usually a finished bit of work and could be taken down verbatim and published with a few corrections as a speech by Lord Rosebery ... An excellent point at all the clinics is the opportunity afforded to the assistants to help in the teaching.' He greatly admired, while at the same time, he somewhat mistrusted the didactic skill and the oratorical talent of those whom he calls the masters of the amphitheatre. 'And such indeed is Professor Dieulafoy' whom he listened to on some Saturday morning in the old and famous Amphitheatre Trousseau, at the Hôtel-Dieu, where each of us, in turn, has been proud of lecturing, and which is still used for teaching purposes. Osler draws a vivid sketch of the master: 'Dieulafoy is an extraordinary dramatic lecturerall the accessories of facial expression and of movements of hands, arms and shoulders are used. A rapid utterance, the short interrogative method, the appeal to the patient, the choice language, a pleasing voice, a keen sense of humor-all combine to make the Saturday clinic at the Hôtel-Dieu a great treat.' (May I add, that under Dieulafoy's original photograph acting as a portrait, this tradition has not yet been lost!) 


\section{Coury}

Osler however, expresses his astonishment that the chairs of the Faculty should sometimes be given to a particular professor, not so much because of his personal specialty, but rather as a homage to his personality; he adds however: 'In practice, it does not work badly.' Already in his day, reforms were being made, with a group of enthusiastic innovators to support them, a majority of indomitable opponents to delay them and many weighty observers to debate them. Osler witnessed the tumultuous demonstrations which attended the progress of the concours d'agrégation in December 1908 and which were sparked by a ministerial initiative aiming at changing the conditions of the test to the detriment of the oldest candidates; he gave an hour by hour description of the events. He recalled with the same precision the disturbance which had been created the year before by the candidacy of a provincial candidate to the chair of anatomy. Were Osler still alive today, he could repeat nearly word for word his chronicle of similar disputes ... 'A Faculty without its troubles is always in a bad way - the waters should be stirred. Some ferments should be brewing; the young men should always be asking for improvements, to which the old men will object. It is a sign of health, and so we may regard these troubles at the Paris medical school-much good will come of them. Not that the appointment of professors will ever be solved. The "concours" seems an admirable plan for the "agrégé", though it is much criticized, and many here are in favour of a less didactic test-of some plan whereby a man's work will tell. The difficulty would be to eliminate favouritism and to get a perfectly impartial jury. The positions are so few . . . and the candidates so numerous.'

And yet, the assessment he made upon his departure from Paris, on the 15 January 1909 , is singularly enthusiastic: 'After a stay of three and a half months, I am leaving Paris with many regrets. I am sorry not to be a member of the Faculty of Medicine; I should be glad to put after my name "Médecin des Hôpitaux"; the position of "chef de clinique" at the Hôtel-Dieu with Professor Dieulafoy would suit me admirably; I could be quite happy as an interne with Professor Raymond at the Salpêtrière, or as an externe with Professor Pierre Marie at the Bicêtre or even as a "stagiaire" at the Cochin with Dr. Chauffard! . . I should like to do the vice versa trick of Anstey's story, and change places with the young P.C.N. in this year's class who will go to the grades of my regrets just mentioned and who about the year 1940 will become dean of this ancient and remarkable medical school.' Incidentally, the man to become Dean at the time of the Second World War was one of my excellent masters, Professor Alphonse Baudouin, a neurologist (1876-1957).

William Osler not only 'understood' French Medicine thanks to his open and penetrating mind; he also 'felt' it with his warm and generous heart. Osler-he gave proof of this-held no less 'reverence' than the French for the values of the mind and for those who transmit them from one generation to the next: 'Only by the labours of transmuters has progress been made possible.' He felt, as one does in France, this unfailing school spirit which marks the free attachment of the pupils to their masters, and he proclaimed this before the students: 'You have all become brothers in a great society, not apprentices, since that implies a master, and nothing should be farther from the attitude of the teacher than much that is meant in that word, used though it be in another sense, particularly by our French brethren in a 


\section{Osler and French Medicine}

most delightful way, signifying a bond of intellectual filiation.'

Upon Osler's departure from Paris, an attack of tonsillitis prevented him from going to Lyons and to Montpellier as he had proposed to do: he made straight for Cannes, where he stayed at the Hôtel Montfleury much frequented by English visitors. I am indebted to my friends Dr. Henri Gimbert and Dr. Jean-Louis Gimbert for the following details. The physician who attended Osler was Dr. Ernest M. Ginner (1876-1963), the son of a British chemist who had settled in Cannes. Dr. Ginner had graduated in England and in France and was appointed to the Sunny Bank Hospital in Cannes. He called as a consulting physician upon Sir Richard Bright, from London, who used to spend the winter in Cannes, Boulevard de la Croisette, where he attended some important and wealthy British patients. The prescription consisted in large pills of calomel, which apparently Osler did not use. He nevertheless recovered and Dr. Henri Gimbert had the opportunity of meeting him at a dinner offered by his British colleagues. Cushing mentions that Osler was then putting the finishing touches to his chapter on Quincke's angioneurotic oedema, erythromelalgia and sclerodermia. Subsequently, the Regius left Cannes for Italy on 8 February 1909. He was to make another short trip to France in the sad period of World War I from 8 October to 15 October 1915; ranking as a Lt.-Colonel of the Medical Corps, he came as an adviser to No. 3 Canadian General Hospital in Camiers, a village of the Pas-de-Calais, near Le Touquet. Meanwhile, the medical work of Sir William Osler had been acknowledged all over the world and France had greatly benefited from it.

Osler's contribution to modern medicine is considerable and it is too well known for us to make yet another detailed evaluation. His work on morbid anatomy, his famous research on blood platelets, on the parasites of malaria, on amoebic dysentery, his studies on tuberculosis, nervous diseases and paediatrics are memorable. In 1899, he made known a new disease the description of which was to be completed a year later by Banti. In 1903, he reported four cases of 'chronic cyanosis with polycythaemia and enlarged spleen', or erythremia - 'as an echo to the paper by Vaquez' (1892 and 1902), to whom he paid tribute and whose priority he spontaneously emphasized. From 1895 to 1903, he devoted several publications to the visceral complications of 'Erythema exsudativum multiforme'; thus, long before the American work of Libman and Sacks (1924), of Baehr and Klemperer (1942), he foresaw the L.E.D. disease, the foremost of those diseases that we now call collagenic. Multiple hereditary telangiectasis, which he described in 1907, bears his name associated in France with that of Rendu. But Osler's name remains most of all connected with his original studies which are penetrating and practically final on infectious endocarditis.

In France the term 'Osler's disease' or 'Jaccoud-Osler endocarditis', exclusively designates the slow types of vegetating endocarditis. Curiously enough, this very odd evolutional notion emanated rather late from Osler's work. His first studies on infectious endocarditis appeared in 1881 and they were the subject of the famous Gulstonian Lectures delivered at the Royal College of Physicians in 1885. His textbook written between 1890 and 1892, gives a description of it that is masterly and complete at the first attempt: the clinical outset, the various types of fever, the cutan- 


\section{Coury}

eous manifestations, the usual absence of cardiac insufficiency, the existence of primary cases and of cases developed on a pre-existing valvular lesion, either rheumatic or congenital, mainly aortic, the pathology of the vegetations, the microbian etiology which he sensed even before the discovery of the streptococcus, the existence of forms with or without the presence of spores in the blood, nothing escapes Osler except perhaps the clubbing of the fingers which was first noted by Major in 1912. Originally Osler mainly emphasized the subacute varieties of the disease; he acknowledged the French works of Charcot and Vulpian (1862), of Lancereaux (1862, 1873), of Deget and Hayem (1863), of Lépine (1869), of Colson (1876). He leaned more toward Jaccoud's concept: 'With regard to the nomenclature, I think the terms "infectious" and "septic", as given by Jaccoud, better than others ... On the other hand, the term "infectious" presupposes no special view as to the nature of the local process, and at the same time indicates, as Jaccoud says, a constant and exclusive character of the disease.' Osler however challenged the malarian origin attributed in France to certain cases of endocarditis with long and intermittent fever. He recalled that the first blood cultures to find the responsible micrococci were attempted by Grancher and by Cornil (1884), but without success; the German bacteriologist Schottmüller had not yet developed the appropriate technique. It is obvious that at the beginning, Osler made no distinction between acute cases causing suppurative infarcts and the slowly developing cases which lead to non-suppurative infarctions. The notion of prolonged cases appeared for the first time in 1893 in relation to two cases: it was confirmed especially in 1909 when Osler was able to call for support ten observed cases of chronic infectious endocarditis with or without fever, the course of which lasted several months or years. In his thesis published in 1897, Henri Godonnèche, a pupil of Jaccoud, drew more particular attention to the slowly developing cases of endocarditis. In 1901, another pupil of Jaccoud, Bergenstein, also devoted his thesis to the apyretic and to the prolonged febrile forms of malignant endocarditis. Osler finished his description of it in 1909; more specifically, he wrote: 'One of the most interesting features of the disease and one to which very little attention has been paid is the occurrence of ephemeral spots of a painful nodular erythema, chiefly in the skin of hands and feet, the "nodosités éphémères" of the French'. By a return of courtesy, the French call them 'Osler's nodes'. The description of the disease which was begun and thus ended by the master of Oxford, was reimported into France, thanks mainly to an article by Professor Robert Debré in the Revue de Médecine in 1919 , the very year of Osler's death. Everything had been said about this disease and the later works only added a few details to Osler's description. It was for his pupil, Dr. Maude Abbott to stress in 1925 the frequency of the cases of endocarditis developed on a congenital defect such as Ductus arteriosus, thus opening the way to surgical prevention. Finally it was only right that another great Britisher-Sir Alexander Fleming - should discover ten years after Osler's death the remedy capable of curing this redoubtable disease and that other Oxford scientists should detail the use of it. In France, as in every other country of the world, both names are associated in the same tribute of admiration: that of the man who identified widespread and inexorable disease, linked with the name of the man who supplied medicine with the means of mastering it. 


\section{Osler and French Medicine}

Gentlemen, we have reached the end of a fine trilogy. Please forgive the speaker, if by using a language which is not his own, he has not measured up to the task. Allow him at least to borrow for the last time a few words from the exceptional author that was William Osler: 'I take it, Sir, that in this Commemorative festival for blessing the fruits of our great men .... our presence here in due order and array confers distinction upon an occasion of which the oration is but an incident.'

\section{REFERENCES}

Aвbott, Maude, et al., Sir William Osler Memorial Volume, Montreal, 1926.

Idem., Classified and annotated Bibliography of Sir William Osler's Publications, Montreal, Medical Museum, McGill University, 1939.

BergensteIn, Contribution a l'étude de la forme apyrétique et de la forme fébrile prolongée de l'endocardite maligne, Thèse, Paris, 1901, Boyer édit.

Bibliotheca Osleriana: Bibliotheca Prima. Oxford, Clarendon Press, 1929, 68-69, 657.

Courville, C. B., 'Sir William Osler and his portraits, with a brief story of the one painted by Seymour Thomas', Bull. Hist. Med., 1949, 23, 353-377.

Cushing, HaRvey, The life of William Osler, 2 vols., Oxford, Clarendon Press, 1925, 20-21 and 136-158.

Godonnk̀CHe, HeNRI, Contribution à l'étude des endocardites infectieuses (Des endocardites infectieuses d̀ marche lente), Thèse, Paris, 1897, Jouve édit.

hahn, André, and Dumartre, Paule, Histoire de la Médecine et du Livre Médical à la lumière des Collections de la Bibliothèque de la Faculté de Médecine de Paris, Paris, Olivier Perrin, 1962, 130, 146.

Hutchinson, R., 'William Osler', Quart. J. Med., October 1949, 18, 72, 275-279.

JobIN, P., 'Osler and medical education', Laval Médical, 1963, 34, 864-869.

LaVeran, Charles, 'Décès de Sir William Osler, Associé étranger', Bull. Acad. Méd., 2 March 1920, 8-10, 207-208.

MARIE, PIERre, 'Osler éducateur', International Association of Medical Museums Bulletin, $1927,9$.

Osler, WIlliam, 'Infectious (so-called ulcerative) endocarditis', Arch. Med., 1881, 5, 44.

Idem., 'The Gulstonian lectures on malignant endocarditis, London, 1885', Brit. med. J., $1885,467,522,577$.

Idem., The principles and practice of Medicine, Edinburgh and London, 1892.

Idem., 'The influence of Louis on American Medicine', Bull. Johns Hopk. Hosp., 1897, 8, 161.

Idem., 'Chronic cyanosis with polycythaemia and enlarged spleen: a new clinical entity', Amer. J. Med. Sci., August 1903.

Idem., 'Multiple hereditary telangiectasis', Quart. J. Med., 1907, 1.

Idem., La pratique de la médecine, Paris, 1908.

Idem., 'Endocardites infectieuses chroniques', Bull. Soc. méd. Hôp. Paris, 1908, 26, 794-796.

Idem., Letter from Paris to the Editor, The Times, 29 December 1908.

Idem., 'Note on the French and German for medical students', Lancet, 1908, ii, 957.

Idem., 'Chronic infectious endocarditis', Quart. J. Med. 1908-9, ii, 219-230.

Idem., 'Impression of Paris: I. teachers and students', J. Amer. Med. Assoc., 1909, 52, 701-703, 771-774.

Idem., 'The "Anatomie Universelle" of Ambroise Paré, Ann. Med. Hist., 1917, 1, 424-425. Idem., $A$ way of life, and other selected writings, New York, Dover Publications Inc., 1958.

Pratt, JosePh, 'Osler as a clinical teacher', Bull. Hist. Med., 1949, 23, 327-335.

Plichet, ANDRé, 'Le centenaire de Sir William Osler', Pr. méd., 10 December 1949, 77.

RolaND, C. G., 'Some Addenda to Abbott's “Classified Bibliography" of Sir William Osler', Bull. Hist. Med., 38, 1964, 78-79. 


\section{Coury}

RouXeau, Alfred, Laennec avant 1806, Paris, Baillère et Fils.

VAQUEZ, HENRI, 'Sur une forme spéciale de cyanose s'accompagnant d'hyperglobulie excessive et persistante', C.R. Soc. Biol. Paris, 1892, 4, 384.

VAQUEZ HENRI and QUISERNE, 'De la polyglobulie progressive comme signe pronostique dans les cyanoses congénitales', C.R. Soc. Biol. Paris, 1902, 54, 915, 1073.

Whrte, WIIlIAM, 'Osleriana since 1926: A bibliography of writings about Sir William Osler', Bull. Med. Lib. Ass., 1940, 28, 183-197.

Anonymous, 'William Osler: a short biography and some tributes to his memory', Brit. med. J., 1920, i, 64-68.

Unpublished documents from: Archives de l'Académie Nationale de Médecine, Archives et Bibliothèque de la Faculté de Médecine de Paris, Comité National de Défense contre la Tuberculose.

Oral information kindly provided by Madame Edouard Rist (Paris) and by Dr. Henri and Dr. Jean-Louis Gimbert (Paris and Cannes). 